\title{
The evidence of medicinal plants in human sediments from Furna do Estrago prehistoric site, Pernambuco State, Brazil
}

I. Teixeira-Santos ${ }^{\text {a, }}$, L. Sianto ${ }^{\text {a }}$, A. Araújo ${ }^{\text {a }}$, K.J. Reinhard ${ }^{\text {b }}$, S.A.M. Chaves ${ }^{\text {a }}$

a Escola Nacional de Saúde Pública Sérgio Arouca - Fundação Oswaldo Cruz, Rio de Janeiro, Brazil

b University of Nebraska, Lincoln, NE, United States

* Corresponding author:

E-mail address: isabeltsantos@gmail.com (I. Teixeira-Santos).

\begin{abstract}
Pollen grains were recovered from six human coprolites associated with five skeletons from Furna do Estrago, Brejo da Madre de Deus county, Pernambuco State, northeast Brazil. The remains are dated between $1730 \pm$ 50 (BETA 145954) and $1610 \pm 70$ (BETA 145955) years BP (before present). Previously, researchers showed that the local population was infected with intestinal parasites. This is a follow-up study to assess whether or not the population used medicinal plants to treat the symptoms of infection. Pollen from anthelminthic plants and other plants with medicinal and analgesic properties were found in all samples in high concentrations. This demonstrates that plants with medicinal properties were used by the population to adapt to the parasites in the area.
\end{abstract}

\section{Keywords:}

Pollen grains

Paleoepidemiology

Paleopharmacopeia

Paleoparasitology

Sediments 


\section{Introduction}

Dietary analyses of coprolites and sediments collected directly from the pelvic region of skeletons reveal dietary patterns, paleo- climate changes, and medicinal plant use (Callen and Cameron, 1960; Fry, 1977; Lee and Devore, 1979; Shafer et al., 1989; Reinhard et al., 1992, 2006; Berg, 2002; Reinhard et al., 2007). Organic remains found in coprolites and sediments include pollen grains, starch granules, phytoliths, fibers, and bone fragments. The analysis of such residues reveals not only what was consumed in an individual's last meals, but also provides information on the environmental context of the site in which they were found (Wing and Brown, 1979; Eaton and Konner, 1985; Fornaciari and Mallegni, 1987; Jurmain, 1990; Berg, 2002). Agricultural practices, the consumption of "preferred" plants, the prehistoric pharmacopeia, and the type of food preparation are some of other activities that can be identified (Riskind, 1970; Bryant, 1974; Pozorski, 1979; Reinhard, 1991; Reinhard et al., 1991; Piperno and Dillehay, 2008).

Based on the relationship between food remains in paleo- environmental context, the frequency of certain items can be used as an indicator of ancient eating habits and the palaeopharmacopeia of ancient peoples (Callen and Martin, 1969; Reinhard and Bryant, 1992; Araújo et al., 1998; Chaves and Reinhard, 2003; Bouchet et al., 2003). Little is known about the Brazilian palaeopharmacopeia used by prehistoric population of Northeast region. The current study was conducted on sediments collected directly from the pelvic regions from primary burials of a hunter-gatherer group that inhabited Northeast Brazil during the recent Holocene (Brothwell and Brothwell, 1971; Lima, 2001; Sonvesso, 2007). The main goal of this study is to identify the pollen grains from plants with medicinal properties to understand the palaeopharmacopeia used by this group.

\section{Material and methods}

\subsection{The samples and Furna do Estrago archaeological site}

Coprolites were collected from the pelvic regions of skeletons found in the Furna do Estrago rock shelter (Fig. 1). The coprolites were collected from primary burials corresponding to the use of Furna do Estrago as a cemetery. This corresponds to the more recent occupations of the site, considering the human bones dated from $1860 \pm 50$ BP (BETA 145954) $1610 \pm 70 \mathrm{BP}$ (BETA 145955). Two samples (A731 and A827) were collected from burial 23, the interment of a 12-year-old boy. An adult female who died between the ages of 35 and 40 years was represented by two samples (A730 and A830) from burial 6. One sample (A728) was associated with a young man in burial 8 who died between the ages of 25 and 27. Finally, a coprolite (A837b) was recovered from a comingled burial of four individuals. This was recorded as burial 87 (Fig. 2). 


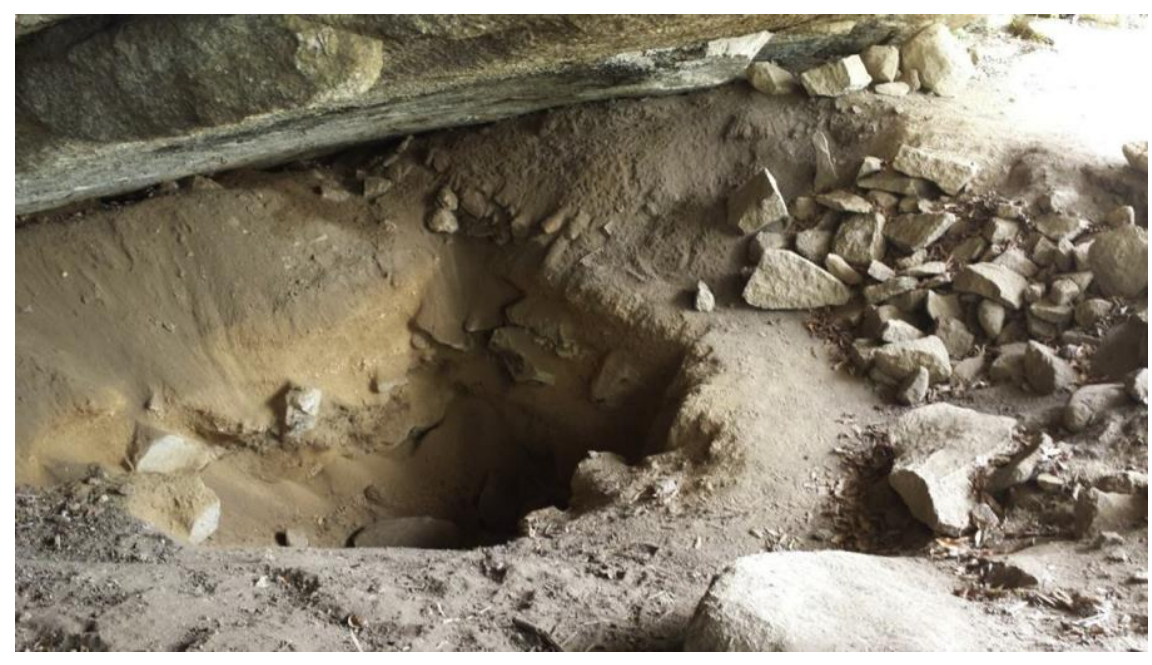

Fig. 1 Archaeological site Furna do Estrago in Brejo da Madre de Deus municipality, Pernambuco State, Brazil. Image captured by: Teixeira-Santos, 2013.

The samples were collected during the archaeological excavations that began in the 1980s. Jeannette Lima coordinated the fieldwork done by an archaeological team from the Catholic University of Pernambuco. The material was sent to the Paleoparasitology Laboratory at Fiocruz and was first analyzed by Duarte (1994) for parasite remains. Since then, the material was stored in the Paleoparasitology Collection of ENSP (Escola Nacional de Saúde Pública). For the purpose of laboratory analysis, the coprolites received different recording numbers, as can be seen in Table 1 .

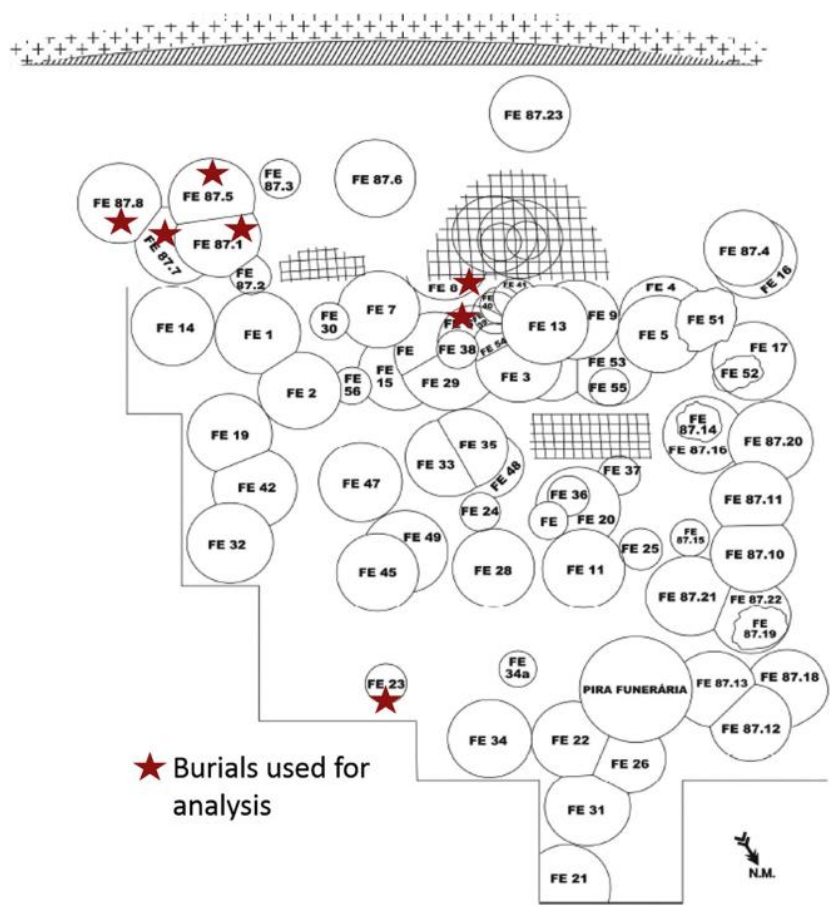

Fig. 2. Distribution of burials in the archaeological site Furna do Estrago, Pernambuco e Brazil. Burials whose samples were collected and used in this paper are marked at the figure. 
Table 1 Identification of sediment samples and their burial provenance.

\begin{tabular}{|c|c|c|c|c|c|}
\hline Sample & Gender & Age & Dates & Funerary artifacts & Burials associated \\
\hline A728 & Male & $25-27$ years & Undefined & Necklace seeds & Burial 8 \\
\hline A730 & Female & $35-40$ years & $1730 \pm 70 \mathrm{AP}$ & Palm mats and ropes & Burial 6 \\
\hline A731 & Male & \pm 12 years & Undefined & Straw and mats fragments & Burial 23 \\
\hline A827 & Male & \pm 12 years & Undefined & Straw and mats fragments & Burial 23 \\
\hline A830 & Female & 35 e 40 years & $1730 \pm 70 \mathrm{AP}$ & Mats, ropes and nets & Burial 6 \\
\hline A837b & Unknown & Unknown & Undefined & None & Burials $87.1,87.5,87.7,87.8$ \\
\hline
\end{tabular}

The archaeological site is located $200 \mathrm{~km}$ inland from the coast of Pernambuco State in the municipality of Brejo da Madre de Deus. This area is in the agreste region. The agreste is a long arid zone that stretches through six northeast Brazilian states. The region displays specific climates according to the Köppen classification: hot semiarid in the caatinga or scrub forest (BSh), hot and humid with autumn-winter rains along mountain slopes, and mesothermal humid at the high altitude forests, atop the mountains. The latter climate is called the Mata Serrana do Bituri, in the brejo de altitude region (Lima, 1985). The site experiences varied climatic conditions, with a mean annual temperature of 20.4 C, highs of $29.6 \mathrm{C}$ in the hot months (November and December), and 16.6 $\mathrm{C}$ in the cooler months (July and August). Annual rainfall ranges from 500 to $1100 \mathrm{~mm}$ (Lima, 2001; Menezes, 2006). The site in prehistory would have been adaptable for human use because it is a sort of refugium, retaining more moisture even during the dry seasons than the surrounding area. Around the site, the agreste is subject to periodic very dry cycles over several years, with scarce or even no rainfall. The local vegetation has recently been changed by the introduction of intensive agriculture and household farming. Today, maize, carrots, beans manioc, and other crops are grown by local farmers, as well as mangos, papayas, dates and other fruit trees. However, around the site one can also find remnants of the native caatinga or scrub forest vegetation, ranging from tree species to shrubs, cacti, and palms.

The rock shelter shows evidence of use and occupation in different periods, as attested by the petroglyphs, hearths, and burials from successive prehistoric human occupations between 11,000 and 1000 BP. During that long period different groups used it for different purposes, including as a dwelling. The archaeological layers accumulated from the end of Pleistocene until the Climate Optimum (CO), is marked by a distinct stratigraphy with seven distinct layers with seven different dates were accumulated over $130 \mathrm{~cm}$ in depth (Lima, 2001). New occupations continued after the CO. Finally, between $1860 \pm 50$ (BETA 145954) and 1610 \pm 70 BP (BETA 145955), the site was used by a hunter-gatherer group as a burial ground for about 200 years. After this the cemetery was abandoned, the site was used again very briefly during the prehistoric period by pottery producing people. During the historical period it was used frequently as a shelter for herds and other animals, travelers, hunters and for feasting by local residents. Previous studies provided information on the local paleoenvironment and the use of the cemetery. Excavations recovered 83 individuals of both sexes and of different ages (Lima, 1984, 1985, 2001; Ferreira et al., 1989; Souza and Alvim, 1992; Duarte, 1994; Carvalho et al., 2003). 


\subsection{Processing of samples}

For analysis and quantification of the pollen grains, $1 \mathrm{~cm} 3$ was taken from each of the six coprolites. The samples analyzed for pollen grains were A728, A730, A731, A827, A830, and A837b. The samples were rehydrated, screened, and treated with acetolysis as described for coprolites (Chaves and Reinhard, 2003, 2006; Reinhard et al., 1991, 2006). In this technique, the material is rehydrated according to Callen and Cameron (1960), followed by the Lutz (1919) spontaneous sedimentation technique. After the addition of a tablet containing 12,500 spores of exotic Lycopodium (for concentration of pollen grains and their subsequent quantification), acetolysis was performed by the addition of acetic anhydride and sulfuric acid. Diagnosis of the pollen types was based on comparison with modern material in the Pollen Reference Collection deposited at the Ecology Laboratory of ENSP and the identification keys by SalgadoLabouriau (1973).

\section{Results}

Results indicated a variety of pollen grains, with a total pollen concentration of $1,238,281$ $\mathrm{pg} / \mathrm{cm}^{3}$ (pollen grains per cubic centi-meter) in sample A730; $181,659 \mathrm{pg} / \mathrm{cm}^{3}$ in sample A728; $92,424 \mathrm{pg} / \mathrm{cm}^{3}$ in sample A827; $38,347 \mathrm{pg} / \mathrm{cm}^{3}$ in sample A731; $1039.46 \mathrm{pg} / \mathrm{cm}^{3}$ in sample A830; and $7137 \mathrm{pg} / \mathrm{cm}^{3}$ in sample A837b (Table 2). The following are the paleoethnobotanical/paleoenvironmental interpretations of the pollen and food findings from each sample: Sample A728 - The species Stryphnodendron barbatiman showed a high pollen concentration of $108,000 \mathrm{pg} / \mathrm{cm}^{3}$. There was also a high concentration $\left(47,700 \mathrm{pg} / \mathrm{cm}^{3}\right)$ of pollen type Sebastiania, from which the latex of some species (Stryphnodendron macrocarpa) is believed to have therapeutic properties. Three more pollen types of ethnobotanical interest were also found, but at lower concentrations: Manihot $8900 \mathrm{pg} / \mathrm{cm}^{3}$, Pisonia, and Croton, $1600 \mathrm{pg} / \mathrm{cm}^{3}$. Twenty-six other pollen types found in the sample suggest environmental interpretations related to vegetation with elements of Astronium, Sapium, Cuphea thymoides, Fabaceae, Zanthoxylum, Tragia, Schinus, Euphorbia, Aspilia, and Eupatorium.

Sample A730 - This sample had a high concentration of $290,800 \mathrm{pg} / \mathrm{cm}^{3}$ pollen grains of the species Stryphnodendron barbatiman. We also found a high concentration of the pollen type Pseudobombax marginatum, $357,900 \mathrm{pg} / \mathrm{cm}^{3}$, which has therapeutic properties according to Paulino et al. (2012). Syagrus has been used as a vermifuge and was represented in this sample by $384,942 \mathrm{pg} / \mathrm{cm}^{3}$. Pisonia was represented by $10,600 \mathrm{pg} / \mathrm{cm}^{3}$. Thirty-six other pollen types with lower concentrations were found. These indicate that the environment in which this person lived contained the following families and genera: Anacardiaceae, Sapium, Phylanthus, Aspilia, Cuphea thymoides, Tragia, Myrtaceae, Erhrythroxylum, Aspilia, and Nyctaginaceae. 
Table 2 Identification and quantification of pollen grains with medicinal properties in samples from the Furna do Estrago archaeological site, Pernambuco State, Brazil.

\begin{tabular}{lrrrrrr}
\hline Pollen type & A728 & A730 & A731 & A827 & A830 & A837b \\
\hline Stryphnodendron barbatiman $^{\mathrm{a}}$ & 2721 & 603 & 549 & 891 & 46 & 7 \\
Croton $^{\text {Manihot }}$ & 41 & 2 & 542 & 110 & 82 & 0 \\
Pseudobombax marginatum $^{\mathrm{a}}$ & 223 & 13 & 217 & 223 & 0 & 1 \\
Sebastiania $^{\mathrm{a}}$ & 0 & 742 & 2 & 0 & 602 & 0 \\
Malvaceae - Sida sp. $^{\mathrm{a}}$ & 1194 & 4 & 0 & 0 & 0 & 2 \\
Syagrus $^{\mathrm{a}}$ & 0 & 1 & 0 & 0 & 4 & 0 \\
Pisonia $^{\mathrm{a}}$ & 0 & 798 & 4 & 4 & 23 & 5 \\
Fevillea $^{\mathrm{a}}$ & 41 & 109 & 16 & 1 & 5 & 52 \\
Undetermined $_{\text {Indeterminable }}$ & 0 & 0 & 0 & 0 & 1609 & 10 \\
Total & 4 & 5 & 8 & 14 & 12 & 11 \\
\hline
\end{tabular}

a Plants with medicinal properties.

Sample A731 - This sample also contained pollen types from the species Stryphnodendron barbatiman with $13,600 \mathrm{pg} / \mathrm{cm}^{3}$, Croton with $13,400 \mathrm{pg} / \mathrm{cm}^{3}$, and Manihot with $5,400 \mathrm{pg} / \mathrm{cm}^{3}$. A total of 27 pollen types with paleoenvironmental relevance were identified. The following types are all related to rainforest vegetation: Combretum, Cassia, and Leguminosae Papilonaceae, Pisonia, Cnidosculus, Phyllanthus, Anacardiaceae, Euphorbiaceae, Neea, Aspilia, and Bidens.

Sample A827 - The species Stryphnodendron barbatiman was represented by $57,307 \mathrm{pg} / \mathrm{cm}^{3}$, suggesting intentional ingestion. Two other pollen types of ethnobotanical interest were identified at lower concentrations: Manihot $14,300 \mathrm{pg} / \mathrm{cm}^{3}$ and Croton $7.000 \mathrm{pg} / \mathrm{cm}^{3}$. The sample showed a representative pollen concentration of $92,424 \mathrm{pg} / \mathrm{cm}^{3}$ with 39 pollen types identified, including: Desmodium, Cassia, Byrsonima, Peixotoa, Tragia, Couepia, Licania, Trixis, Borreria, Terminalia, and pollen types from the families Apocynaceae, Arecaceae, Euphorbiaceae, and Anacardiaceae, among others.

Sample A830 - This sample presented the pollen type Fevillea with a high concentration: $611,517 \mathrm{pg} / \mathrm{cm}^{3}$. Menezes (2006) has reported medicinal use of this genus in the Brazilian Sertão. Three other pollen types of ethnobotanical relevance were Pseudobombax marginatum with $228,796 \mathrm{pg} / \mathrm{cm}^{3}$, Stryphnodendron barbatiman with $17,482 \mathrm{pg} / \mathrm{cm}^{3}$, and Croton with $31,164 \mathrm{pg} / \mathrm{cm}^{3}$. Another 27 pollen types indicate semideciduous tree and bush vegetation: Peixotoa, Schinus, Mimosa acustipula, Boreria, Justicia, Aspilia, Pisonia, Ruellia, Myrcia, Memora, and types from the families Anacardiaceae, Bromeliaceae, Arecaeae I and II, Sapindaceae, Malvaceae, Rutaceae, and Rhamnaceae.

Sample A837b - This sample showed the lowest pollen con-centration of all the samples analyzed, or $7137 \mathrm{pg} / \mathrm{cm}^{3}$, without any significant concentration that would demonstrate some intentional plant use. The pollen types identified (28) were interpreted as merely paleoenvironmental indicators, namely: Cassia, Pera, Bowdichia, Sapium, Euphorbia, Pisonia, Zanthoxylum, M. acustipula, Rutaceae, Poaceae, Leguminosae Papilonaceae, and Arecaceae, among others. 


\section{Discussion}

The fact that pollen grains were observed from family Arecaceae (palm trees), genus Syagrus, is consistent with findings from previous studies, such as Souza (1995) and Tunala (2000), which describe the presence of remains from palm trees adhered to buried skeletons. As the coprolites and sediments entered into direct contact with the palm leaf mats that were used to wrap the bodies, often after decomposition of the body, this finding in a single sample may have been a case of contamination of the coprolite by the context. However, there could be an enthnobotanical explanation. Palm leaves used to make the mats would not likely carry pollen with them, especially the extremely high concentrations found in sample A730. As defined by Chaves and Reinhard (2006) and Reinhard et al. (2006), the very high value represented by sample A730 is due to human ingestion of polleniferous material from the plant.

Some areas of northeastern Brazil such as Furna do Estrago are now characterized by elements of semideciduous forests and also typical elements of humid areas of remaining brejos de altitude. Two thousand years ago, they probably presented a scenario close to that attested by the pollen grains identified in our samples: dense rainforest (trees and brush) with elements of Anacardiaceae (Astronium Schinus), Apocynaceae, Bignoniaceae, Combretaceae, Euphorbiaceae, Leguminosae (Cassia), Lythraceae, Melastomataceae (Byrsonima), Mimosaceae (M. acustipula), Myrtaceae, Rutaceae, Cucurbitaceae, Rhamnaceae (Zyziphus), and Sapindaceae. This particular archaeological site is located close to the Mata Serrana (mountain forest), which has a humid climate and includes some of these same plant specimens in its composition. The high concentration of pollen grains found in coprolites and pelvic sediments points that ancient individuals were consuming these plants.

We highlight the presence of Stryphnodendron barbatiman (with astringent properties) in samples A728, A730, and A731, which is of ethnobotanical significance, probably involving intentional use. Other types identified in high concentrations were Croton, Manihot, Pseudobombax, Anacardium, and an unidentified Convolvulaceae. Among the pollen grains that were identified, some are from plants with exceptional medicinal properties such as Sida sp. This is particularly important when compared to previous parasitological analyses (Duarte, 1994) identified in Table 3. Following the logic of Chaves and Reinhard (2006), the case for the use of Sida sp. as a remedy for worm infections symptoms is strong. Cheno am type was also found. Cheno am pollen represents a great number of species, only a few of which have medicinal properties. As discussed by Reinhard et al. (1985), identification of specific Chenopodium anthelminthic species must still be based on seeds.

Pollen grains of plants known for their anthelminthic properties were found in two samples positive for intestinal helminths; and in one from the two negative ones for parasites (Table 3). Since intestinal infections cause symptoms such as abdominal colic, intermittent diarrhea or constipation, vomiting, nausea, appetite changes, weakness, dizziness, and weight loss (Rey, 2008), inferences can be drawn. First, the two individuals that were negative for parasites had cleared their infections by ingesting plants with medicinal properties to treat intestinal symptoms; therefore, when the coprolites were analyzed they were already free from parasite infection. Second, the plants were part of the food habit and non-intentionally consumed to prevent helminthic infections (Reinhard et al., 1985, 2000; Chaves and Reinhard, 2003, 2006; Teixeira-Santos, 2010). However, the use of anthelminthic plants in the diet as a prophylaxis for parasite infection was established by Reinhard et al. (1985) for hunter-gatherers in Utah.

Self-medication is not exclusive to humans, since it is practiced by various other species, including primates (Huffman, 1997, 2001; Huffman and Caton, 2001; Huffman and Hirata, 2004; 
Fowler et al., 2007). Thus, self-medication by prehistoric humans is logical, suggesting that animal-plant-parasite interaction may have occurred among the people of Furna do Estrago archaeological site.

The near absence of helminth infection at the site, as demonstrated by Duarte (1984), can be explained by the model established by Reinhard (1988) for the American Southwest. Among hunter-gatherer bands, small band size, diffuse regional populations, high band mobility, and presence of natural anthelminthics in hunter-gatherer diets limited parasitism. Parasitism was promoted in descendent agricultural Pueblo and communities by contaminated water sources, concentrated populations, more sedentary life, permanent villages, absence of effective sanitation, activities centered on water (agriculture), and activities that expanded wetlands including irrigation of all types.

Table 3 Previous parasitological diagnosis from Duarte (1994)

\begin{tabular}{ll}
\hline Samples & Parasitological results \\
\hline A728 & Negative \\
A730 & Positive \\
A731 & Positive \\
A827 & Positive \\
A830 & Positive \\
A837b & Negative \\
\hline
\end{tabular}


Beyond the Reinhard model, other factors including the degree of resistance to infection, could have played a role. The dry environment would have been less suitable to a diverse array of para- sites that are dependent on moist edaphic conditions to achieve maturity and infective stages. This reinforces a model that is still proposed for the occupation of the semiarid, wish shows evidence of consumption of plants with medicinal properties as part of a local population's eating habits (Alves and Souto, 2011).

A great amount of Sebastiania was found in sample A728. Species of the family Euphorbiaceae, including Sebastiania, are popularly used as antiviral, antimicrobial, antiinflammatory, antiulcer, antihypertensive and muscle relaxant remedies in many Brazilian regions. Experiments with Sebastiania corniculata revealed that it has antimicrobial activities (Silva et al., 2014). Feliu et al. (2011) reports that this genus has a species that is used in traditional medicine as a laxative and to treat acne and mental disturbances. This sample containing Sebastiania pollen was negative for parasites. Sebastiania has a variety of effects that would have helped to alleviate a variety of symptoms related to diverse maladies. The antimicrobial effects would have been useful for treating intestinal infections with protozoa or bacteria. Protozoa or bacteria in coprolites were not found, so no association between infection and treatment could be established.

The high concentration of Syagrus and Pisonia pollen grains in sample A730, a positive sample for helminths, may indicate that this individual was trying to relieve symptoms of a parasitic infection. The tea from the bark and flower, or fruit juices from Syagrus genus, is used as a vermifuge by Brazilian indigenous population Guarani. They also use of infusion to relieve pain at tooth roots (Lindenmayer, 2008). Pisonia is also used as a laxative in folk medicine, helping to free the intestine from parasites (Almeida and Bandeira, 2010).

In sample A830, a high concentration of pollen grains of the genus Fevillea was found. This plant has many medicinal applications, so the discovery of the pollen is noteworthy. Oil from seeds of Fevillea trilobata may be consumed as part of diet, since this plant has a high level of protein (Ventura and Paulo, 2000). In addition, this plant is used to combat hepatitis (Cruz, 1965) and can be used as an aphrodisiac (Júnior, 1981). A decoction of the pods is used to relieve intestinal cramps (Grandi et al., 1989). The dried leaves are administered as medicine for snakebite used externally (Júnior, 1981) and the leaf juice for internal use as medicine for snake- bites (Grandi et al., 1989). The seeds can be consumed to combat rheumatism and when cooked are also used as febrifuge (Edwall, 1906). This plant is employed as a treatment for hookworm infection and also kidney problems resulting from yellow fever. It can also be used to relieve dyspepsia and stomachaches (Revilla, 2002). The seeds have internal use as medicine for gastro-intestinal atony, flatulence, constipation, liver disease, congestion and colic (Matta, 2003). Jaundice and inflammation of the liver are treated with lightly toasted seeds (Grandi et al., 1989). According to Duarte (1994), sample A830 was positive for the intestinal helminthes, Trichuris trichiura. Considering the properties of $F$. trilobata in treating intestinal symptoms, the high concentration of pollen grains probably points to a putative treatment of the infection.

Samples A728, A730, A731 and A827 showed a high concentration of Stryphnodendron barbatiman pollen grains. Chemically, the extracts include tannins, alkaloids, starch, flavonoids, proanthocyanidins, resinous materials, mucilage, dyes, and saponin (Holanda and Freitas, 1992). Carvalho (1972) asserts that the aqueous extract of the bark of this plant has a significant effect on wound healing and has anti-inflammatory, analgesic properties and may act as a protection to the gastric mucosa. It was also demonstrated the efficiency of 
aqueous preparations to treat ulcers. Being positive for helminth samples A730, A731, and A827, and the high concentrations of pollen grains of this species is an indicative that such individuals were seeking some sort of treatment for the symptoms they were experiencing, such as abdominal pain and cramping.

Reinhard (1993) demonstrated that multiple coprolites recovered from a single body can provide distinct dietary signals. This was demonstrated experimentally in living people by Dean (2006) and Kelso and Solomon (2006). This phenomenon is represented by the samples from burials 6 and 23. The two coprolites from the 12 year old male in burial 6 contrast markedly in the amounts of S. barbatiman, Syagrus, and Fevillea. Fevillea makes up $67 \%$ of the pollen in sample A830, but was not encountered in sample A730. The spectrum from sample A730 is dominated by S. barbatiman (26\%), and Syagrus (35\%) compared to just $2 \%$ S. barbatiman and $1 \%$ Syagrus in sample A830. The percentages of Pseudobombax marginatum are comparable with 25 and 32 respectively. The samples from burial 23 also contrast with $S$. barbatiman represented by $41 \%$ in sample A731 and $71 \%$ in sample A827. Croton codominates sample A731 with $40 \%$ of the pollen count compared to just $9 \%$ of the A827 count. These differences show how important it can be to sample multiple coprolites from the same individuals to capture evidence of varying plant consumption over several hours or days before death.

\section{Conclusion}

This is a preliminary approach of Furna do Estrago ancient hu- man strategies to cope with environmental conditions and disease, evidenced by a predominantly plant rich diet base. Little is known about Brazilian prehistoric pharmacopeias. This study allowed us to establish connections between infection and selection of pollen- iferous plant products that have curative properties. The data show that Brazilian indigenous people have an ancient recognition of medicinal active plants pointing that in ancient times the human- eparasite interaction gave rise to a need for medicinal plants. The pollen concentrations bare witness of human adaptation to pa- thology through medicinal plants.

\section{Acknowledgements}

Research funding was provided by the Brazilian National Research Council (CNPq), CAPES (Ciência sem Fronteiras) and Rio de Janeiro Research Foundation (FAPERJ).

\section{References}

Almeida, V.S., Bandeira, F.P.S.F., 2010. O significado cultural do uso de plantas da caatinga pelos quilombolas do Raso da Catarina, município de Jeremoabo, Bahia, Brasil. Rodrigue sia 61 (2), 195-209.

Alves, R.R.N., Souto, W.M.S., 2011. Ethnozoology in Brazil: current status and perspectives. Journal of Ethnobiology and Ethnomedicine 7-22. 
Araújo, A., Reinhard, K., Bastos, O.M., Costa, L.C., Pirmez, C., Irriguez, A.M., Vicente, A.C., Morel, C.M., Ferreira, L.F., 1998. Paleoparasitology: perspectives with new techniques. Revista do Instituto de Medicina Tropical de São Paulo 40, 371-376.

Berg, G.E., 2002. Last meals: recovering abdominal contents from skeletonized re- mains. Journal of Archaeological Science 29, 1349-1365.

Bouchet, F., Guidon, N., Dittmar, K., Harter, S., Ferreira, L.F., Chaves, S.A.M., Reinhard, K., Araújo, A., 2003. Parasite remains in archaeological sites. Memoirs, Institute Oswaldo Cruz 98 (1), 47-52. Brothwell, D., Brothwell, P., 1971. A alimentação na antiguidade. Editorial Verbo, Lisboa.

Bryant, V.M., 1974. Prehistoric diet in Southwest Texas: the coprolite evidence. American Antiquity $39,407-420$.

Callen, E.O., Cameron, T.W.M., 1960. A prehistoric diet revealed in coprolites. New Science 8, 35-40.

Callen, E.O., Martin, P., 1969. Plant remains in some coprolites from Utah. American Antiquity 34, 329331.

Carvalho, A.R. de, 1972. A cura pelas plantas e diversos meios de grande poder curativo, third ed. Folco Masucci, São Paulo, p. 360.

Carvalho, A.O., Souza, S.M.F.M., Queiroz, N.A., Silva, A.F., Alves, M.A.M., Silva, M.I.C., 2003. Nota prévia sobre traços de desarticulação e descarnamento em um esqueleto do sítio arqueológico Furna do Estrago, Brejo da Madre de Deus, Pernambuco. Caninde 3, 293-299.

Chaves, S.A.M., Reinhard, K.J., 2003. Paleopharmacology and pollen: theory, method and application. Memoirs, Institute Oswaldo Cruz 98, 207-211.

Chaves, S.A.M., Reinhard, K.J., 2006. Critical analysis of prehistoric evidence of medicinal plant use, Piauí, Brazil. Palaeogeography, Palaeoclimatology, Palae- oecology 237, 110-118.

Cruz, G.L., 1965. Livro verde das plantas medicinais e industriais do Brasil, first ed.Belo Horizonte.

Dean, G., 2006. The science of coprolite analysis: the view from Hinds cave. Palaeogeography, Palaeoclimatology, Palaeoecology 237, 67-79.

Duarte, A.N., 1994. Estudo paleoparasitológico em coprólitos do sítio arqueológico da Furna do Estrago, município Brejo da Madre de Deus, Pernambuco. Itaguaí. Dissertação de Mestrado em Parasitologia Veterinária, Instituto de Biologia. Universidade Federal Rural do Rio de Janeiro, p. 117.

Eaton, S.B., Konner, M., 1985. Paleolithic nutrition: a consideration of its nature and current implications. New England Journal of Medicine 312, 283e289.

Edwall, G., 1906. Ensaio para uma sinonímia dos nomes populares das plantas indígenas do estado de São Paulo. Boletim da Comissão Geográfica e Geológica de São Paulo 2 (16), 11.

Feliu, D.A., Palanivel, M.G., Rajkapoor, B., Kumar, R.S., 2011. Hepatoprotective and antioxidant effect of Pisonia aculeata L. against CCl4-induced hepatic damage in rats. Scientia Pharmaceutica 76, 203215.

Ferreira, L.F., Araújo, A., Confalonieri, U., Lima, J.M.D., 1989. Trichuris trichiura eggs in human coprolites from the archaeological site of Furna do Estrago, Brejo da Madre de Deus, Pernambuco, Brazil. Memoirs, Institute Oswaldo Cruz 84, 581-582.

Fornaciari, G., Mallegni, F., 1987. Palaeonutritional studies on skeletal remains of ancient populations from the Mediterranean area: an attempt to interpretation. Anthropologischer Anzeiger 45, 361-370.

Fowler, A., Koutsioni, Y., Sommer, V., 2007. Leaf-swallowing in Nigerian chimpanzees: evidence for assumed self-medication. Primates 48, 3.

Fry, G.F., 1977. Analysis of Prehistoric Coprolites from Utah. In: Anthropological Papers 97. University of Utah, p. 45. 
Grandi, T.S.M., Trinade, JA da, Pinto, M.J.F., Ferreira, L.L., Catella, A.C., 1989. Plantas medicinais de Minas Gerais, Brasil. Acta Botânica Brasílica 3 (2), 185-224.

Holanda, N., Freitas, A.S., 1992. Potencialidades agroindustriais da Amazônia. SUDAM, Belém.

Huffman, M.A., 1997. Current evidence for self-medication in primates: a multi- disciplinary perspective. Yearbook of Physical Anthropology 170-200.

Huffman, M.A., 2001. Self medicative behavior in the African great apes: an evolutionary perspective into the origins of human traditional medicine. Bioscience 651-661.

Huffman, M.A., Caton, J.M., 2001. Self-induced increase of gut motility and the control of parasitic infections in wild chimpanzees. International Journal of Primatology 329-346.

Huffman, M.A., Hirata, S., 2004. An experimental study of leaf swallowing in captive chimpanzees: insights into the origin of a self-medicative behavior and the role of social learning. Primates 45, 113118.

Júnior, S., 1981. Coleção edições do Pasquim. Plantas eróticas, vol. 81. Rio de Janeiro: Codecri.

Jurmain, R., 1990. Paleoepidemiology of a central California prehistoric population from CA-Ala-329: dental disease. American Journal of Physical Anthropology 81, 333-342.

Kelso, G.K., Solomon, A.M., 2006. Applying modern analogs to understand the pollen content of coprolites. Palaeogeography, Palaeoclimatology, Palae- oecology 237, 80-91.

Lee, R.B., Devore, I., 1979. Man the Hunter. Aldine Publishing Company, Hawthorne, New York.

Lima, J.M.D., 1984. Pesquisa arqueológica no Município do Brejo da Madre de Deus -Pernambuco. In: Symposium in Recife, 26. Universidade Católica de Pernambuco, pp. 9-60.

Lima, J.M.D., 1985. Arqueologia da Furna do Estrado Brejo da Madre de Deus - Pernambuco. Dissertação de Mestrado apresentada ao Programa de Pós-graduação do Grau de Mestre em Antropologia. Recife, p. 143.

Lima, J.M.D., 2001. O Sítio Arqueológico Furna do Estrago e Brasil em uma perspectiva antropológica e social. Tese de doutorado (Tese não defendida). Universidade Nacional Autonoma de Mexico, p. 168.

Lindenmayer, D.S., 2008. Etnobotânica em Comunidades Indígenas Guaranis no Rio Grande do Sul. Universidade de Santa Cruz do Sul, Rio Grande do Sul, p. 44.

Lutz, A., 1919. O Schistosomun mansoni e a schistosomatose segundo observações feitas no Brasil. Memoirs, Institute Oswaldo Cruz 19, $121 \mathrm{e} 155$.

Matta, A.A., 2003. Flora médica brasiliense, third ed. In: Série Poranduba 3 Editora Valer e Governo do Estado do Amazonas, Manaus, p. 356.

Menezes, A.V.A., 2006. Estudos dos macro-restos vegetais do sítio arqueológico Furna do Estrago, Brejo da Madre de Deus, Pernambuco, Brasil. Dissertação de mestrado em arqueologia. Recife, p. 116.

Paulino, C.R., Henriques, G.P.S.A., Moura, O.N.S., Coelho, M.F.B., Azevedo, R.A.B., 2012. Medicinal plants at the Sítio do Gois, Apodi, Rio Grande do Norte State, Brazil. Brazilian Journal of Pharmacology 22 (1), 29-39.

Piperno, D.R., Dillehay, T.D., 2008. Starch grains on human teeth reveal early broad crop diet in northern Peru. Proceedings, National Academy of Science 105, 1962-1967.

Pozorski, S.G., 1979. Prehistoric diet and subsistence of the Moche Valley, Peru. World Archaeology $11(2), 163-184$.

Reinhard, K.J., Ambler, J.R., McGuffie, M., 1985. Diet and parasitism at Dust Devil Cave. American Antiquity 50, 819-824.

Reinhard, K.J., 1988. Cultural ecology of prehistoric parasitism on the Colorado Plateau as evidenced by coprology. American Journal of Physical Anthropology 77, 355-366. 
Reinhard, K.J., 1991. Recent contributions to new world archaeoparasitology. Parasitology Today 7 (4), 81-82.

Reinhard, K.J., 1993. The utility of pollen concentration in coprolite analysis: expanding upon Dean's comments. Journal of Ethnobiology 9, 31-44.

Reinhard, K.J., Hamilton, D.L., Hevly, R.H., 1991. Use of pollen concentration in paleopharmacology: coprolite evidence of medicinal plants. Journal of Ethnobiology 11, 117-134.

Reinhard, K.J., Bryant Jr., V.M., 1992. Coprolite analysis: a biological perspective on archaeology. In: Schiffer, M.B. (Ed.), Advances in Archaeological Method and Theory 4. University of Arizona Press, Tucson, pp. 245-288.

Reinhard, K.J., Geib, P.R., Callahan, M.M., Hevly, R.H., 1992. Discovery of colon contents in a skeletonized burial: soil sampling for dietary remains. Journal of Archaeological Science 19, 697705.

Reinhard, K.J., Araújo, A., Ferreira, L.F., 2000. The role of mummy studies in paleoparasitology. Chungara 32, 111-115.

Reinhard, K.J., Bryant Jr., V.M., Vinton, S.D., 2007. Reinterpreting the pollen data from Dos Cabezas. International Journal of Osteoarchaeology 17, 531-541.

Reinhard, K.J., Edwards, S.K., Damon, T.R., Meier, D.K., 2006. Pollen concentration analysis of ancestral pueblo dietary variation. Palaeogeography Palaeoclimatology, Palaeoecology 237, 92109.

Revilla, J., 2002. Plantas úteis da Bacia Amazônica, vol.1. INPA/SEBRAE, Manaus.

Rey, L., 2008. Parasitologia, forth ed. Guanabara Koogan, Rio de Janeiro.

Riskind, D.H., 1970. Pollen analysis of human coprolites from Parida Cave. In: Alexander, R.K. (Ed.), Archaeological Excavations at Parida Cave, Val Verde County, Texas. Papers of the Texas Archeological Salvage Project 19, Appendix A, pp. 89-101.

Salgado-Labouriau, M.L., 1973. Contribuição a Palinologia dos Cerrados. Ac. Bras. Ciências, Rio de Janeiro.

Shafer, H.J., Marek, M., Reinhard, K.J., 1989. Mimbres burial with associated colon remains from the NAN Ranch Ruin, New Mexico. Journal of Field Archaeology 16, 17-30.

Silva, I.S.M., Santos, R.F.E.P., Barbosa, A.M., Santos, K.S., Amorim, M.R., Mendonça, F.M.R., Lucena, I.V., Melo, T.V.C., Lins, G.S., Sarmento, P.A., Padilha, F.F., Bastos, L.S.A., 2014. Evaluation of in vitro biological potential of plant species Sebastiania corniculata (Euphorbiaceae). BMC Proceedings 8 (4), 40.

Sonvesso, S.S., 2007. Variações na acumulação de matéria orgânica, ao longo do Holoceno, em sedimentos da região costeira de Ubatuba e São Paulo. Instituto Oceanográfico da Universidade de São Paulo (Dissertação de Mestrado).

Souza, S.M.F.M., Alvim, M.C., 1992. A População Pré-histórica da Furna do Estrago: Adaptação Humana ao Agreste Pernambucano. Symposium 34 (2), 123-145.

Souza, S.M.F.M., 1995. Estresse, doença e adaptabilidade: Estudo comparativo de dois grupos pre histo ricos em perspectiva biocultural (Tese de Doutorado). Escola Nacional de Saúde Pública, Fundação Oswaldo Cruz, Rio de Janeiro, p. 245.

Teixeira-Santos, I., 2010. Resíduos alimentares, infecções parasitárias e evidência do uso de plantas medicinais em grupos pré-históricos das Américas (Dissertação de mestrado). Escola Nacional de Saúde Pública, Fundação Oswaldo Cruz, Rio de Janeiro, p. 103.

Tunala, E.G., 2000. Paleoepidemiologia da Enterobíase humana: Revisão de literatura e reexame de coprólitos do sítio arqueológico Furna do Estrago, Brejo da Madre de Deus, Pernambuco e Brasil. Monografia. Fundação Oswaldo Cruz, Rio de Janeiro, p. 24. 
Ventura, A.P.M., Paulo, M.Q., 2000. Avaliação das características físico-química do óleo de Fevillea trilobata. In: Reunião da Sociedade Brasileira de Química. Anais, Poços de Caldas. Resumo.

Wing, E.S., Brown, A.B., 1979. Paleonutrition: Method and Theory in Prehistoric Foodways. Academic Press, New York. 